\title{
The Treatment of PPCP-Containing Sewage in an Anoxic/Aerobic Reactor Coupled with a Novel Design of Solid Plain Graphite-Plates Microbial Fuel Cell
}

\author{
Yi-Tang Chang, ${ }^{1}$ Chu-Wen Yang, ${ }^{1}$ Yu-Jie Chang, ${ }^{2}$ Ting-Chieh Chang, ${ }^{1}$ and Da-Jiun Wei ${ }^{1}$ \\ ${ }^{1}$ Department of Microbiology, Soochow University, 70 Linhsi Road, Shilin District, Taipei 11102, Taiwan \\ ${ }^{2}$ Department of Earth and Life Science, University of Taipei, Taipei 11048, Taiwan \\ Correspondence should be addressed to Yi-Tang Chang; ytchang@scu.edu.tw
}

Received 10 May 2014; Accepted 16 July 2014; Published 14 August 2014

Academic Editor: Ilona Sárvári Horváth

Copyright (c) 2014 Yi-Tang Chang et al. This is an open access article distributed under the Creative Commons Attribution License, which permits unrestricted use, distribution, and reproduction in any medium, provided the original work is properly cited.

Synthetic sewage containing high concentrations of pharmaceuticals and personal care products (PPCPs, mg/L level) was treated using an anoxic/aerobic (A/O) reactor coupled with a microbial fuel cell (MFC) at hydraulic retention time (HRT) of $8 \mathrm{~h}$. A novel design of solid plain graphite plates (SPGRPs) was used for the high surface area biodegradation of the PPCP-containing sewage and for the generation of electricity. The average $\mathrm{COD}_{\mathrm{Cr}}$ and total nitrogen removal efficiencies achieved were $97.20 \%$ and $83.75 \%$, respectively. High removal efficiencies of pharmaceuticals, including acetaminophen, ibuprofen, and sulfamethoxazole, were also obtained and ranged from $98.21 \%$ to $99.89 \%$. A maximum power density of $532.61 \mathrm{~mW} / \mathrm{cm}^{2}$ and a maximum coulombic efficiency of $25.20 \%$ were measured for the SPGRP MFC at the anode. Distinct differences in the bacterial community were presented at various locations including the mixed liquor suspended solids and biofilms. The bacterial groups involved in PPCP biodegradation were identified as Dechloromonas spp., Sphingomonas sp., and Pseudomonas aeruginosa. This design, which couples an A/O reactor with a novel design of SPGRP MFC, allows the simultaneous removal of PPCPs and successful electricity production.

\section{Introduction}

Pharmaceuticals and personal care products (PPCPs) are being paid more public attention as emerging organic contaminants (EOCs) in ecosystems. In Taiwan, the existence of pharmaceuticals pollution can be attributed to incomplete municipal sewage collection systems and inappropriate recycling and treatment programs for waste medical materials. Pharmaceutical sewage can be treated by municipal wastewater treatment plants (WWTPs), but the effluent obtained by such plants introduces residues into the hydrological cycle [1]. Natural surface water systems, such as rivers, reservoirs, and oceans, are widely distributed in Taiwan and are, thus, prone to contamination. Similarly, urban groundwater reservoirs are likely to be contaminated by pharmaceuticals from sewage. The concentration of such pharmaceuticals has been found to range from ng/L to $\mu \mathrm{g} / \mathrm{L}$ and can even reach $\mathrm{mg} / \mathrm{L}$ levels in sanitary landfill leachates. Typical examples of the pharmaceutical drugs found in such sewage in Taiwan include analgesics, antibiotics, and nonsteroidal anti-inflammatory drugs (NSAID); examples are acetaminophen (ACE), sulfamethoxazole (SMX), and ibuprofen (IBU); such compounds are often detected at relatively high concentrations $(\mu \mathrm{g} / \mathrm{L})$ in the influent of municipal WWTPs [2].

Anoxic-aerobic coupled systems (A/O systems) have been applied to the treatment of a wide range of municipal wastewaters and industrial wastewaters of low-to-high strength concentrations. The advantages of $\mathrm{A} / \mathrm{O}$ systems include a high overall treatment efficiency with respect to $\mathrm{BOD}$ and nutrients, a reduced need for sludge disposal, a lower consumption of chemicals, and a greater potential for resource recovery [3]. The combination of aerobic and anoxic degradation pathways in the $\mathrm{A} / \mathrm{O}$ system has been reported as aiding the overall degradation efficiency of PPCPs. The removal efficiencies for PPCPs in municipal wastewater vary on a case-by-case basis due to differences in the biological processes and the target PPCPs. For example, biofiltration of 
wastewater through biological activated carbon has shown good potential for the efficient removal of PPCPs (>90\%), but sand biofilters have a poor efficiency [4]. Sulfonamides have been shown to be removed in the range from $18.5 \%$ to $37.2 \%$ using an anoxic/anaerobic/aerobic (A2O) system, but higher removal efficiencies from $53.3 \%$ to $73.3 \%$ were obtained using an oxidation ditch [5]. Thus, it is necessary to clarify the contribution to sewage treatment efficiency of each different reactor in an $\mathrm{A} / \mathrm{O}$ system.

Energy is required to keep the regular operations at an A/O system fully powered, for example, to provide oxygen $\left(\mathrm{O}_{2}\right)$ to the aerobic reactor. Recently, microbial fuel cells (MFCs) have been found to be able to provide an innovative renewable energy source that is both green and clean, as well as having a low carbon footprint $[6,7]$. The potential for electrical generation of MFCs is being developed and this approach as a source of green energy has the potential to reduce various operational costs (electricity) including aeration and recirculation/process pumping. However, when applied, the two-chamber MFC A/O system is limited in terms of the amount of electrode design. Alternative approaches that can be implemented include improving the electrode design and/or modifying the system by using various chemical catalysts. For example, modifying the cathode by adding a noble metal such as Pt or a nonnoble metal such as $\mathrm{Fe}^{3+}$ or $\mathrm{Mn}^{4+}$, which can then act as a chemical mediator, is able to significantly increase the PD of MFCs $[8,9]$. Such advances in electricity production either need specific carbon-based materials or have to include noble metals at extremely high cost [10], both of which retard the practical development of such systems for MFCs that are coupled with the biological treatment of wastewater. In addition, some of the above mediators are known to be toxic to the growth of bacteria, which are central to biodegradation.

Graphite electrodes in a MFC system are good in terms of power production compared to various metals, such as iron, aluminum, and stainless steel [11]. Biofilms on the graphite electrodes are known to contribute to power production in the MFC system. Different types of graphite cathode/anode electrodes, including graphite plates, sheets, felts, rods, and papers, have been developed to increase electricity output [12]. In fact, the bacterial biofilm formed on the graphite material is also able to biodegrade sewage, even EOCs. The development of high specific surface area graphite cathode/anode electrodes should result in great benefits in a MFC $\mathrm{A} / \mathrm{O}$ system in terms of generating electricity and sewage removal. Moreover, the bacterial community structures and their functions are complex in a MFC A/O system. Till now, there has been little information available on the influence of PPCP-containing sewage on the various dynamic bacterial communities present in $\mathrm{A} / \mathrm{O}$ systems and on electricity generation during biological treatment by an $\mathrm{A} / \mathrm{O}$ system.

The objective of this study is to design and implement a MFC system that is combined with an $\mathrm{A} / \mathrm{O}$ reactor and to use this system to process PPCP-containing sewage for the first time. MFC solid plain graphitic plates (SPGRPs) were designed to generate bacterial electricity and to remove PPCPs in a highly effective manner. The removal efficiencies, including $\mathrm{COD}, \mathrm{N}$, and $\mathrm{P}$, when treating the sewage, were measured using an integrated MFC A/O system. At the same time, PPCP biodegradation was assessed. The spatial bacterial communities and their major functions were carefully evaluated using biomolecular methods, namely, PCR-DGGEcloning. The biodiversity of the bacterial communities at various locations, such as mixed liquor suspended solids (MLSS) and biofilms, was compared across the MFC A/O system. This study provides an alternative approach to the biological treatment of municipal/industrial wastewater that contains PPCPs; specifically, it involves the coupling of a twochamber MFC to an A/O reactor. The specific functions of the various members of the bacterial population present in the reactors were clarified in terms of a series of biochemical reactions within the MFC A/O system.

\section{Material and Methods}

2.1. Chemicals. Three target pharmaceutical drugs among potential PPCPs were selected for this study, ACE, SMX, and IBU. These drugs are commonly found in WWTP municipal wastewater in Taiwan. ACE was purchased from Fluka at purity of $>98 \%$. SMX and IBU were obtained from Sigma-Aldrich at purity of $>99 \%$ and Sigma at purity of $>99.9 \%$, respectively. The organic solvents used in this study were all HPLC grade with purity higher than 99.9\%. All other chemicals were reagent grade with purity above $99 \%$. The Milli-Q water was double-distilled and deionized by a Millipore water purification system.

2.2. The MFC A/O System. Figure 1 shows the pilot-scale coupled MFC A/O system used in this study. The sewage influent consisted of a mixture of condensed artificial PPCP-containing sewage and tap water in a stabilized tank $(25,000 \mathrm{~mL})$ that was controlled to a temperature between $8^{\circ} \mathrm{C}$ and $12^{\circ} \mathrm{C}$. The anoxic reactor $(3,940 \mathrm{~mL})$ was designed as the inner tank and its temperature was controlled to be within the range from $26^{\circ} \mathrm{C}$ to $29^{\circ} \mathrm{C}$, while the aerobic reactor $(11,565 \mathrm{~mL})$ was designed as the outer tank. The MFC system consisted of the inner tank (cathode chamber) and outer tank (the anode chamber) separated by two proton exchange membranes (PEM, Nafion N117, DuPont Nafion PFSA membrane). The total area of PEM in the MFC A/O system was $68.40 \mathrm{~cm}^{2}$ and had the ability to transport hydrogen as protons from the anode (anoxic tank) to the cathode (aerobic tank). SPGRPs $(96 \mathrm{~mm} \times 36 \mathrm{~mm} \times 5 \mathrm{~mm})$ with high specific surface areas $\left(20,267.22 \mathrm{~mm}^{2}\right.$ for each SPGRP) were used for two different purposes in this study, with one set being in the cathode chamber and another set being in the anode chamber. The SPGRPs were fixed by two PTFE-covered stainless steel bars. Copper wires were used to connect all the SPGRPs within the MFC system. The anoxic reactor included eleven SPGRPs that were designed to allow the development of bacterial biofilms on the cathode (called the cathode catalysts or the biocathode) that would increase electricity generation by the MFC. In contrast, the anode chamber consisted of ten SPGRPs that were designed to allow the formation of biofilms that would aid the removal of artificial PPCPs from the sewage. 


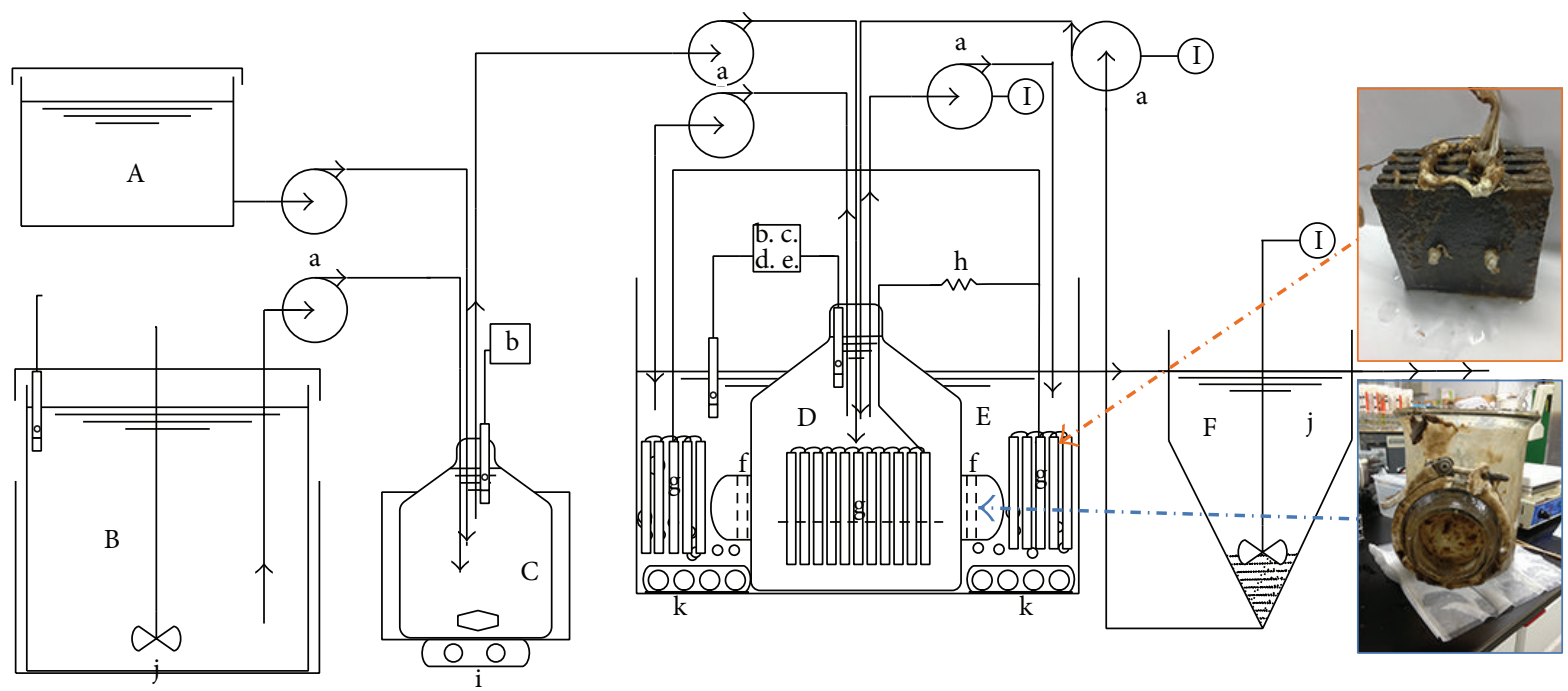
(A) Filtered tap water
(B) Concentrated 30X sewage substrate tank
(C) Mixing tank
(D) Anoxic reactor (anode chamber)
(E) Aerobic reactor (cathode chamber)
(F) Settling clarifier
(I) Sludge recycle route

(a) Peristaltic pump

(b) $\mathrm{pH}$ meter

(c) ORP meter

(d) DO meter

(e) Heating rod

(f) Proton exchange membrane (PEM)
(g) Graphite carbon plates (GCP)
(h) Resistance $(1 \mathrm{k} \Omega)$
(i) Magnetic stirrer
(j) Overhead stirrer
(k) Air diffusers

FIGURE 1: Schematic diagram of the A/O reactor and the MFC coupled system.

TABLE 1: Components of the artificial PPCP-containing sewage (per liter) used in this study.

\begin{tabular}{ll}
\hline Component & Weight $(\mathrm{mg})$ \\
\hline SMX & 2 \\
ACE & 30 \\
IBU & 20 \\
Whole milk & 119 \\
(KLIM, Nestlé) & 30 \\
Saccharide & 11.76 \\
Urea & 6.3 \\
$\mathrm{KH}_{2} \mathrm{PO}_{4}$ & 5.6 \\
$\mathrm{NH}_{4} \mathrm{Cl}$ & 0.14 \\
$\mathrm{FeCl}_{3}$ & $52.64 \mu \mathrm{L}$ \\
$\mathrm{Acetic}$ acid (99.7\%) & Drops were used to adjust the $\mathrm{pH}$ to 7.4 \\
$\mathrm{NaOH}(10 \mathrm{~N})$ &
\end{tabular}

2.3. Inoculation and Experimental Operation of the MFC A/O System. The original source of the active sludge used to inoculate the pilot-scale coupled MFC A/O system came from a secondary sedimentation tank at the Neihu WWTP, Taipei, Taiwan, which is used to treat PPCP-contained sewage. To avoid the influence of the complex content found in real sewage during PPCP biodegradation, artificial sewage containing the target PPCPs was used in this study. Table 1 presents the components present in the artificial PPCPcontaining sewage used in this study. The COD/N/P ratio of influent artificial sewage is about $257.16: 13: 1.96$, which is quite close to the best composition $(\mathrm{C} / \mathrm{N} / \mathrm{P}=100: 5: 1)$ for municipal wastewater when carrying out biological treatment at a WWTP. Activated sludge in the settlement tank $(154,000 \mathrm{~mL})$ was set up to be $100 \%$ recycled into the anoxic reactor because increasing the sludge retention time will reduce the operation costs. Water parameters, including $\mathrm{pH}$, ORP, and DO, were obtained by real-time monitoring of all tanks. Table 2 lists the operating parameters of the MFC $\mathrm{A} / \mathrm{O}$ system. In order to confirm the ability of the system to remove PPCPs and to be able to observe the shifts in bacterial community present in the MFC A/O system, the influent concentrations of ACE, SMX, and IBU were designated to be 30,2 , and $20 \mathrm{mg} / \mathrm{L}$, respectively, which are about 1,000-fold higher concentrations than those present in sewage effluent from Taiwan. The continuous flow rate of the sewage influent was controlled to be $32.33 \mathrm{~mL} / \mathrm{min}$ during this experiment. The hydraulic retention time (HRT) was set up to be $8 \mathrm{~h}$, which consisted of $2.04 \mathrm{~h}$ in the anoxic reactor and $5.96 \mathrm{~h}$ in the aerobic reactor. Two experimental phases were carried out as part of this study. Phase I was designed to have the A/O system coupled with MFC system in steady operation for the biological treatment of artificial sewage without PPCPs and this lasted 95 days. Phase II involved treatment of PPCPcontaining sewage and took place immediately after Phase I; this phase lasted for 28 days. The treatment of the PPCPs, the water parameters $\left(\mathrm{COD}_{\mathrm{Cr}}, \mathrm{N}\right.$, and $\left.\mathrm{P}\right)$, and the bacterial community present were examined regularly.

2.4. Electricity Measurements and Calculations. Power density $(\mathrm{PD})$ and coulombic efficiency $\left(E_{C}\right)$ were selected to be evaluated as measures of the electricity generation by the MFC system [13]. Voltage $(V)$ was regularly measured 
TABLE 2: Operating parameters for the MFC A/O reactor with a HRT of $8 \mathrm{~h}(\text { mean } \pm \mathrm{SD})^{2}$.

\begin{tabular}{|c|c|c|}
\hline Water parameters (unit) & Anoxic reactor (anode chamber) & Aerobic reactor (cathode chamber) \\
\hline $\mathrm{pH}$ & $8.07 \pm 0.33$ & $7.48 \pm 0.31$ \\
\hline Temperature $\left({ }^{\circ} \mathrm{C}\right)$ & $26.75 \pm 1.23$ & $29.58 \pm 1.62$ \\
\hline ORP $(\mathrm{mV})$ & $-393.51 \pm 61.9$ & $121.97 \pm 42.61$ \\
\hline $\mathrm{DO}\left(\mathrm{mg} \mathrm{L}^{-1}\right)$ & $\mathrm{ND}^{1}$ & $4.22 \pm 0.45$ \\
\hline $\operatorname{MLSS}\left(\mathrm{mg} \mathrm{L}^{-1}\right)$ & $\mathrm{ND}^{1}$ & $1956.07 \pm 566.51$ \\
\hline SVI $\left(\mathrm{mL} \mathrm{g}^{-1}\right)$ & $\mathrm{ND}^{1}$ & $218.82 \pm 78.15$ \\
\hline $\mathrm{F} / \mathrm{M}$ & $\mathrm{ND}^{1}$ & $0.19 \pm 0.1$ \\
\hline $\mathrm{F} / \mathrm{V}$ g BOD $\left(\mathrm{m}^{3} \cdot \text { day }\right)^{-1}$ & $\mathrm{ND}^{1}$ & $0.26 \pm 0.14$ \\
\hline
\end{tabular}

${ }^{1} \mathrm{NA}$ : not available.

${ }^{2}$ Average concentrations in the MFC A/O system during Phase I and Phase II (125 days).

using a multimeter (LTlutron DM-9090, Taiwan) via a data acquisition system and this was converted to PD. PD is the power ( $P$ : the definition is the time rate of energy transfer) per cross-sectional area (projected) of the anode $(A)$ according to following equations:

$$
\begin{gathered}
I(\mathrm{~mA})=\frac{V}{R}, \\
P(\mathrm{~mW})=I \times V, \\
\mathrm{PD}\left(\mathrm{mW} / \mathrm{m}^{2}\right)=\frac{P}{A},
\end{gathered}
$$

where $P$ is the power, $I$ is the current $(\mathrm{mA})$, and $R$ is the resistance.

The $E_{C}$ is calculated based on the ratio of total electrons recovered as $I$ to maximum possible electrons recoverable if all substrate removal produces current; this is calculated using the following equation:

$$
E_{C}=\frac{C_{P}}{C_{\max }} \times 100 \%,
$$

where $C_{P}$ is the total coulombs calculated by integrating the current over time. $C_{\max }$ is the theoretical amount of coulombs that can be produced from the artificial wastewater, calculated using the following equations:

$$
\begin{gathered}
C_{P}=I \times \text { HRT, } \\
C_{\text {max }}=F f S_{\mathrm{COD}} V_{\text {anode }}
\end{gathered}
$$

where HRT is hydraulic retention time in the MFC A/O system (s); $F$ is Faraday's constant $(96,485 \mathrm{C} / \mathrm{mol}$ of electrons); $f$ is the number of moles of electrons produced per mole of sewage $\left(1 / 8 \mathrm{~mol}\right.$ of electrons/g COD); $S_{\mathrm{COD}}$ is the difference in COD between the influent and effluent in the anode chamber (anoxic reactor); $V_{\text {anode }}$ is the effective volume of anode volume.

2.5. Water Parameters Analysis. Samples of artificial PPCPcontaining sewage were initially passed through a $1.20 \mu \mathrm{m}$ glass-fiber membrane and then refiltered through a $0.45 \mu \mathrm{m}$ nylon membrane. Samples for water parameter analysis were acquired from the same reactor and at the same time as the microbial samples. Water parameters, including temperature,
$\mathrm{pH}, \mathrm{SS}, \mathrm{VSS}$, and $\mathrm{COD}_{\mathrm{Cr}}$, were analyzed and this was done by following the procedures from the Standard Methods for the Examination of Water and Wastewater [14]. Total nitrogen (T-N) and total phosphate (T-P) were measured using test kits, namely, Merck spectroquant Nova 60. $\mathrm{NH}_{4}{ }^{+}-\mathrm{N}, \mathrm{NO}_{2}{ }^{-}-$ $\mathrm{N}, \mathrm{NO}_{3}{ }^{-}-\mathrm{N}$, and $\mathrm{PO}_{4}{ }^{3-}-\mathrm{P}$ were measured by ion chromatography (IC, Metrohm 883 Basic IC, USA). Real-time pH/ORP and DO were monitored using a $\mathrm{pH} / \mathrm{ORP}$ meter (LTlutron pH/ORP-208 meter, Taiwan) and a DO meter (EZDO, PDO408, Taiwan), respectively.

2.6. PPCPs Analysis. Filtered sewage samples are dried into a powder on a freeze vacuum evaporator (Labconco, USA) at $-50^{\circ} \mathrm{C}$. Extracted samples were concentrated by hexane and diluted using acetonitrile (ACN) to adjust the concentration correctly. The stock solution of PPCPs for the HPLC standards was prepared by serial dilution in ACN and stored in dark-brown glass containers at $4^{\circ} \mathrm{C}$ to prevent photolysis of the PPCPs. Samples and standards were injected into the HPLC system to determine the concentration of PPCPs. The HPLC system was equipped with a UV detector (YL-9100, Young-Lin, Korea) and C18 column $(250 \times 4.6 \mathrm{~mm}$, Thermo Scientific, USA). The operating conditions of HPLC were as follows: $15 \mu \mathrm{L}$ injection sample and $1.2 \mathrm{~mL} / \mathrm{min}$ mobile phase composed grade ACN and $0.02 \mathrm{M}$ phosphoric acid (PA) in the gradient program. The recovery range for the PPCPs in samples was from $75 \%$ to $95 \%$ and the losses were probably due to limitations of the analytical methods. The detection limit of this approach (MDL) to the analysis of the target PPCPs was $5 \mu \mathrm{g} / \mathrm{L}$. Triplicate analyses of the PPCPs were carried out on each sample.

\subsection{Bacterial Community}

2.7.1. DGGE. The genomic DNA of microorganisms involved in the A/O system was extracted from MLSS, SPGRP biofilms, and PEM biofilms in the MFC A/O system using a soil genomic DNA purification kit (Gene Mark, Taiwan). Bacterial 16S rDNA genes were selectively amplified from the purified DNA products by PCR. The V6-V8 region of $16 \mathrm{~S}$ rDNA was selected using the forward primer $968 \mathrm{~F}-\mathrm{GC}$ clamp and the reverse primer 1392R [15]. The DNA product was separated by DGGE profiling using DCode Universal Mutation Detection System (Bio-Rad Laboratories, Inc., Hercules, 
California, USA) and $40 \%$ to $65 \%$ gradient gel at $60^{\circ} \mathrm{C}$ and $110 \mathrm{~V}$ for $16 \mathrm{~h}$. The acrylamide percentage used for the DGGE electrophoresis gel was $8 \%$ and the denaturing agents were formamide and urea. Richness indices (RIs), which are related to the band numbers on the DGGE profiles, were used to represent the variation in biodiversity of the MFC A/O system. This allows the assessment of the changes in richness of the bacterial populations.

2.7.2. Cloning. The genomic DNA of microorganisms involved in the A/O system was extracted from MLSS, GRP biofilms, and PEM biofilms in the MFC A/O system using a soil genomic DNA purification kit (Gene Mark, Taiwan). Bacterial 16S rDNA genes were selectively amplified from the purified DNA products by PCR. Clone libraries were then constructed after amplifying the full length (including the V1-V8 region) of the $16 \mathrm{~S}$ rRNA using the forward primer E9F and the reverse primer U1510R [16]. The amplicons were purified using an EasyPure PCR/Gel Extraction kit (Bioman, Taiwan). The clean product was then cloned using the pGEMT Easy Vector Systems kit (Promega, Madison, Wisconsin, USA) and transformed into competent Escherichia coli DH5a cells as described by the manufacturer. The transformed $E$. coli was incubated on LB agar plates at $37^{\circ} \mathrm{C}$ overnight and the next day the blue-white screening method was applied to select all white colonies from each population. Plasmids DNA from each colony was then extracted using an EasyPure Plasmid DNA miniprep kit (Bioman, Taiwan). Plasmids with the correct DNA insert were identified by the PCR amplification using the primers M13-F (5'-GTT-TTC-CCA-GTCACG-AC- $\left.3^{\prime}\right)$ and M13-R ( $5^{\prime}$-ACA-GGA-AAC-AGC-TATGA- $\left.3^{\prime}\right)$. The DNA sequencing of the various $16 \mathrm{~S}$ rRNA inserts was carried out by the Genomics Company, Taiwan. All sequences were compared with reference microorganisms from the GenBank database using BLAST. The closest $16 \mathrm{~S}$ rDNA sequences to the 16S rRNA sequences obtained from the bacteria making up the biodegradation bacterial populations were retrieved and all the sequences were then aligned using Clustal X software. A phylogenetic tree was constructed by the neighbor-joining method using Molecular Evolutionary Genetics Analysis, version 5 (MEGA 5.1 Beta 3) software. Bootstrap values of $>1,500$ (from 5,000 replicates) are indicated as at the nodes in the phylogenic analysis.

\section{Results}

3.1. Treatment of PPCP-Contained Sewage. Figure 2 outlines the variation in water parameters of the MFC A/O system during Phases I and II (totally 125 days). There is no significant difference in sewage removal when Phase I and Phase II are compared (ANOVA), which indicate that the performance of biological treatment is not affected by the presence of PPCPs. The total removal efficiency of the $\mathrm{COD}_{\mathrm{Cr}}$ averaged $97.20 \%$. The contributions of the anoxic reactor and aerobic reactor to $\mathrm{COD}_{\mathrm{Cr}}$ removal were $44.80 \%$ and $50.61 \%$, respectively. The total removal of $\mathrm{T}-\mathrm{N}$ averaged $83.75 \%$ for the complete $\mathrm{A} / \mathrm{O}$ system. In contrast, the total removal of T-P averaged only $39.24 \%$, but this was because the sludge settlement in secondary settlement tank was not disposed

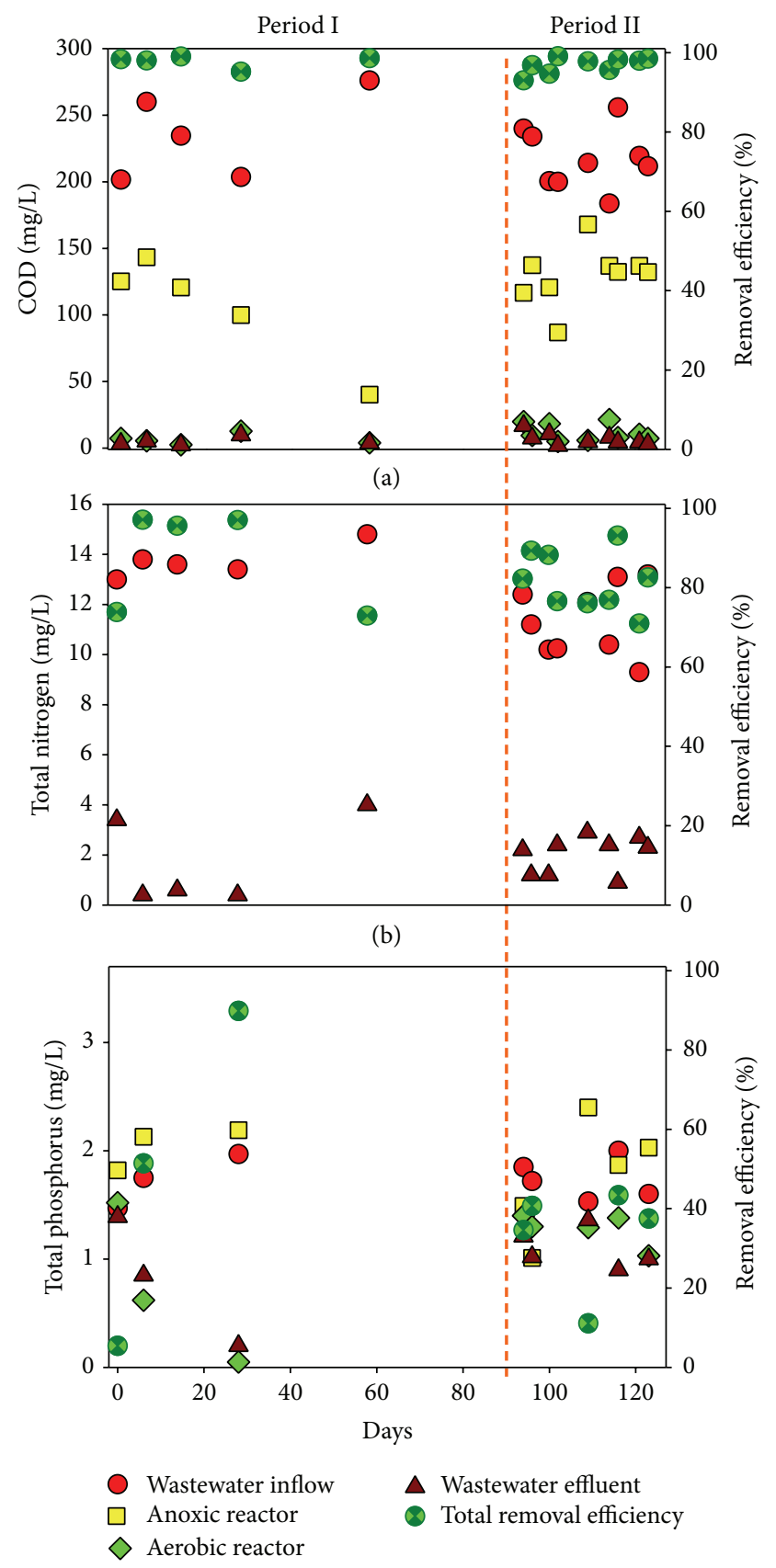

(c)

FIGURE 2: Variation in water parameters in the MFC A/O reactor: (a) $\mathrm{COD}_{\mathrm{Cr}}$; (b) T-N; (c) T-P. Phase $\mathrm{I}=95$ days; Phase $\mathrm{II}=28$ days.

of on a regular basis. The present MFC A/O system showed a better biological treatment performance compared to a previous study where the removal efficiency for $\mathrm{COD}_{\mathrm{Cr}}, \mathrm{T}-\mathrm{N}$, and T-P during the biological treatment of sewage containing 20 PPCPs by a WWTP at $8 \mathrm{~h}$ HRT was found to be $75.0 \%$, $42 \%$, and $66.0 \%$, respectively [17].

Table 3 shows the average concentrations of specific nutrients that were present in the high strength PPCP-containing sewage of the MFC A/O system over Phases I and II. 
TABLE 3: Changes in the sewage nutrients across the MFC A/O system (mean $\pm \mathrm{SD})^{1}$.

\begin{tabular}{lccrr}
\hline Water parameters $(\mathrm{mg} / \mathrm{L})$ & Influent & Anoxic reactor (anode) & Aerobic reactor (cathode) & Effluent \\
\hline $\mathrm{NH}_{4}{ }^{+}-\mathrm{N}$ & $1.767 \pm 0.894$ & $9.021 \pm 3.623$ & $0.087 \pm 0.078$ & $0.036 \pm 0.049$ \\
$\mathrm{NO}_{2}{ }^{-}-\mathrm{N}$ & $0.375 \pm 0.152$ & $0.258 \pm 0.043$ & $0.408 \pm 0.211$ & $0.344 \pm 0.088$ \\
$\mathrm{NO}_{3}{ }^{-}-\mathrm{N}$ & $1.555 \pm 0.501$ & $0.260 \pm 0.076$ & $0.335 \pm 0.124$ & $1.033 \pm 0.670$ \\
$\mathrm{PO}_{4}{ }^{3-}-\mathrm{P}$ & $1.318 \pm 0.293$ & $1.777 \pm 0.497$ & $0.501 \pm 0.201$ & $1.090 \pm 0.422$ \\
\hline
\end{tabular}

${ }^{1}$ Average concentrations in the MFC A/O system during Phase I and Phase II (125 days).

The SPGRP biofilms within the MFC provided simultaneous nitrification and denitrification in the study. Basically, biofilms on the SPGRP bring about denitrification in the anoxic reactor, while the SPGRP biofilms allow parallel nitrification and aerobic oxidation in the aerobic reactor. The membrane of the PEM contains sulfonic acid groups, which are able to bind the ammonia present during the aerobic nitrification. The concentration of $\mathrm{NH}_{4}{ }^{+}-\mathrm{N}$ in effluent was reduced from $1.767 \pm 0.894 \mathrm{mg} / \mathrm{L}$ to $0.036 \pm 0.009 \mathrm{mg} / \mathrm{L}$ in effluent by nitrification/denitrification through the complete A/O reactor process. The total removal efficiency for $\mathrm{NH}_{4}{ }^{+}-$ $\mathrm{N}$ was $97.96 \%$. A significantly increased concentration of $\mathrm{NH}_{4}{ }^{+}-\mathrm{N}$ was found in the anoxic reactor of $9.02 \pm 3.62 \mathrm{mg} / \mathrm{L}$ because of the mixing of sewage influent and $100 \%$ recycled settlement sludge. The concentrations of nitrite and nitrate were found to be decreased in the anoxic reactor. A removal efficiency of $83.28 \%$ for nitrate was measured with a biological reduction from $1.555 \pm 0.501 \mathrm{mg} / \mathrm{L}$ to 0.260 $\pm 0.076 \mathrm{mg} / \mathrm{L}$. Nitrification was found to occur in aerobic reactor, where the concentration of nitrate was increased from $0.260 \mathrm{mg} / \mathrm{L}$ to $1.033 \mathrm{mg} / \mathrm{L}$. Since the A/O process is not designed as a T-P removal system, the low removal efficiency observed is not unexpected. The concentration of $\mathrm{PO}_{4}{ }^{3-}-$ $\mathrm{P}$ was slightly decreased from $1.31 \pm 0.29 \mathrm{mg} / \mathrm{L}$ to $1.090 \pm$ $0.422 \mathrm{mg} / \mathrm{L}$. Moreover, the concentration of T-P averaged $1.8675 \pm 0.4412 \mathrm{mg} / \mathrm{L}$ in anoxic reactor, which is greater than that of the aerobic reactor at $1.0738 \pm 0.500 \mathrm{mg} / \mathrm{L}$. This can be ascribed to intracellular polyphosphate (poly-P) being taken up into the biomass present in the aerobic reactor and then being released in the anoxic reactor. However, the target PPCPs in the present system might have had an effect on nutrient removal in the A/O MFC system. For example, $50-500 \mathrm{mg} / \mathrm{L}$ of IBU and ACE have been shown to inhibit nitritation/denitritation and phosphorus uptake/release rates in a sequence of batch reactors [18].

3.2. Occurrence and Removal of PPCPs. Figure 3 shows the variation of PPCP concentration throughout the MFC A/O system. High concentration PPCPs (mg/L level) in the artificial sewage were removed at an efficiency greater than $98 \%$ in this MFC A/O system. The PPCP removal performances were compared and this gave the following result (ANOVA, $P<0.05)$ : ACE $(99.89 \%)>\operatorname{IBU}(99.01 \%)>\operatorname{SMX}(98.21 \%)$. A similar trend in terms of removal efficiencies of $99.8-99.9 \%$ for ACE, $99.1-99.5 \%$ for IBU, and $73.8-80.8 \%$ for SMX was found using a conventional activated sludge WWTP system linked to two pilot-scale membrane bioreactor treatment (MBR) systems [19]. In general, antibiotics such as SMX are more resistant to biodegradation in most WWTPs than other pharmaceuticals. It has been reported that $10-400 \mathrm{mg} / \mathrm{L}$ SMX is able to inhibit microbial activity in activated sludge by more than $20 \%$ [20]. In one study, an average removal efficiency of $65 \%$ for SMX was achieved by MBR under anoxic and aerobic conditions [21].

PPCPs at a ppb level could still be detected by HPLC in the effluent of the conventional A/O process. The ACE, SMX, and IBU effluent concentrations were $23.9 \pm 2.34 \mu \mathrm{g} / \mathrm{L}$, $23.7 \pm 1.1 \mu \mathrm{g} / \mathrm{L}$, and $179.9 \pm 17.7 \mu \mathrm{g} / \mathrm{L}$, respectively, and these levels still might pose an ecological risk in terms of the aquatic environment. Since groundwater constitutes the main source of public drinking water supplies in many countries, people who drink PPCPs-contaminated water may suffer an adverse effect on their growth and reproduction. Specific pharmaceuticals at low concentrations (ng/L) have become an important issue, particularly because of their toxicity towards living organisms. For example, about 50\% to $90 \%$ of the original SMX dose and its metabolites are released into the environment and these then bioaccumulate via biotic factor and abiotic factors in the food chain [22]. SMX induces antibiotic resistance in bacteria and hazard quotients in WWTP effluent have revealed that these chemicals may pose an ecotoxicological risk to algae [23]. The occurrence of ACE has been reported in the aquatic environment and there is an important need to address the potential toxic effects of ACE on nontarget environmentally exposed organisms [24]. Exposure to low concentrations $(10-100 \mathrm{ng} / \mathrm{L})$ of IBU has been found to result in a significant decrease in the activity of Gammarus pulex [25].

3.3. Electricity Production by the MFC A/O System. Figure 4 demonstrates electricity generation by the MFC A/O system. Initially, polarization curves were obtained by measuring the power generation at various external resistances (from $510 \mathrm{~K} \Omega$ to $1 \Omega$ ) and are shown in Figure 4(a). We selected $1 \mathrm{~K} \Omega$ to measure I and A during this study. The existence of PPCPs in sewage does not seem to have affected the electric generation (ANOVA). Figure 4(b) presents the average PD, which was found to be $285.15 \mathrm{~mW} / \mathrm{m}^{2}$; furthermore, the maximum PD value achieved during Phase II was $532.61 \mathrm{~mW} / \mathrm{m}^{2}$. The $E_{C}$ values ranged widely from $2.77 \%$ to $25.20 \%$ over the 125 days of the study and averaged $12.62 \%$ overall. Direct electron transfer from microbial cells to electrodes occurs at very low efficiency and a higher PD by a SPGRP MFC. It modifies the material used as the cathode catalyst in order to increase the efficiency of the oxidation-reduction reaction. In this study, the novel design used here allows the formation 


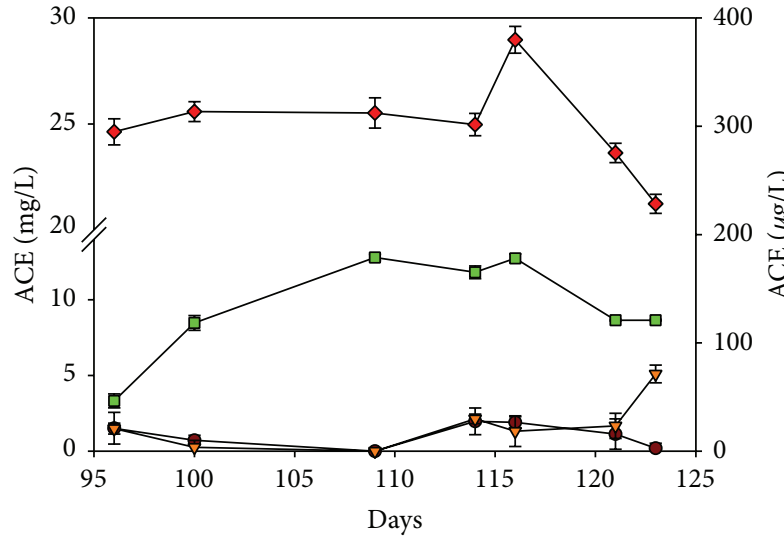

(a)

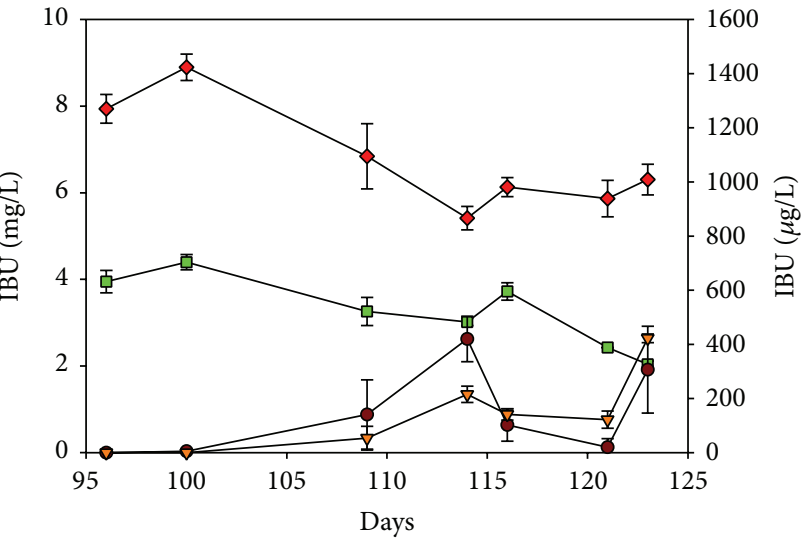

(b)

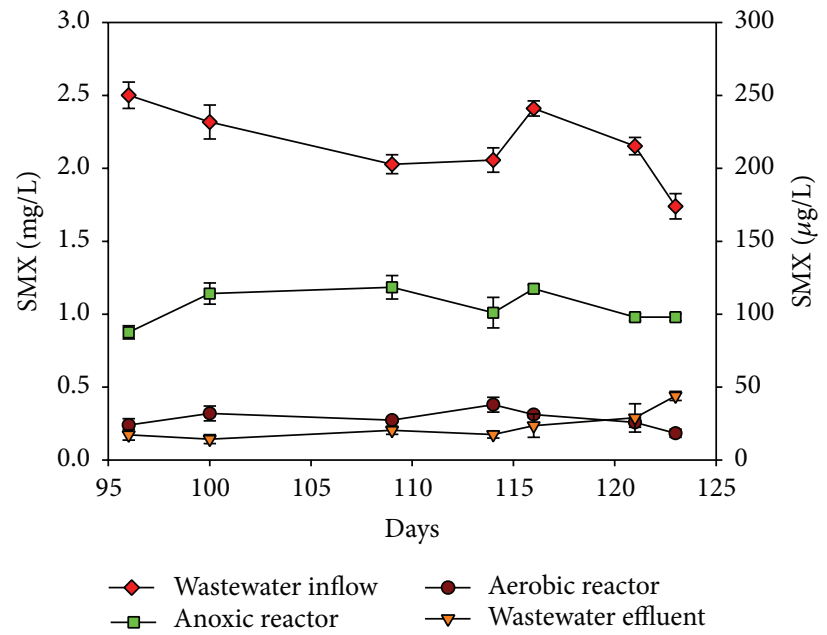

(c)

FIGURE 3: Variation in targeted PPCPs in the MFC A/O system during Phase II: (a) ACE; (b) IBU; (c) SMX. The concentrations in the sewage influent $(\checkmark)$ and in the anoxic reactor $(\boldsymbol{\nabla})$ are presented on the left- $Y$ axial $(\mathrm{mg} / \mathrm{L})$. The concentrations in the aerobic reactor $(\boldsymbol{\nabla})$ and in the sewage effluent $(\bullet)$ are presented on the right- $Y$ axial $(\mu \mathrm{g} / \mathrm{L})$.

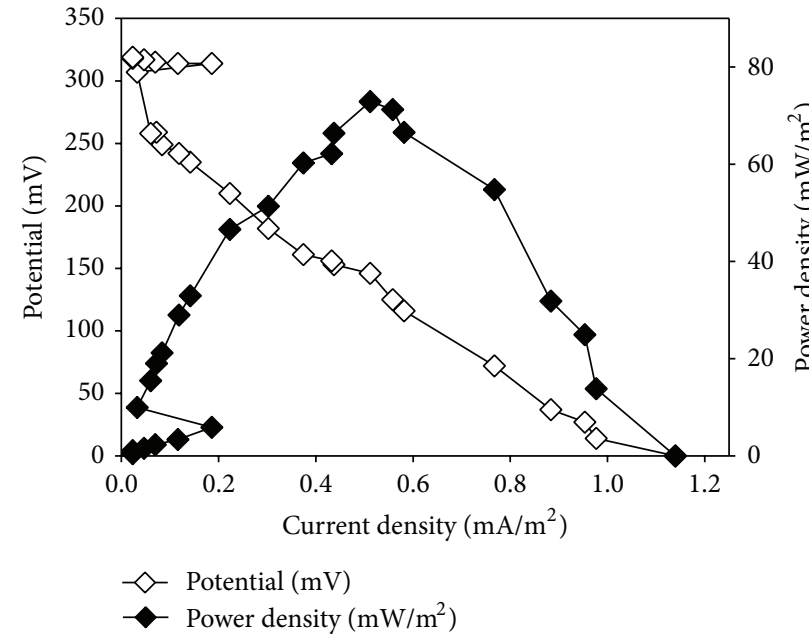

(a)

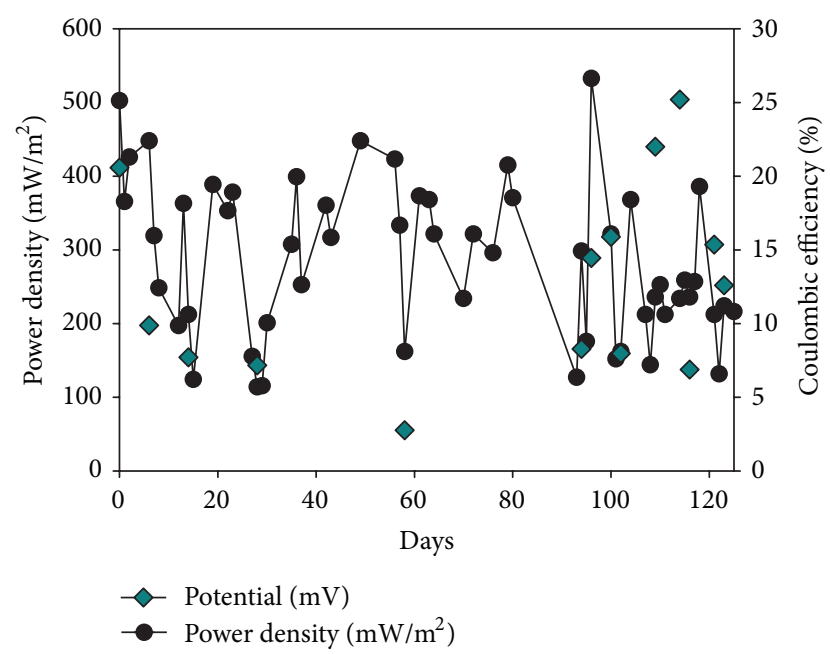

(b)

FIGURE 4: Electrical generation by the A/O reactor coupled with the novel MFC system: (a) polarization curve; (b) power density and coulombic efficiency. 
TABLE 4: The richness index (RI) on the 109th day of Phase II obtained from the DGGE profiles allows assessments of the variation in biodiversity across the various areas of the novel MFC A/O system.

\begin{tabular}{|c|c|c|c|c|}
\hline \multirow{2}{*}{\multicolumn{2}{|c|}{ Same bands ${ }^{1} /$ different bands $^{2}$ (difference ratio ${ }^{3}$ ) }} & \multicolumn{3}{|c|}{ Anoxic reactor (anode) } \\
\hline & & MLSS & SPGRP biofilm & PEM biofilm \\
\hline \multirow{3}{*}{ Aerobic reactor (cathode) } & MLSS & $3 / 18(85.71 \%)$ & $7 / 16(69.56 \%)$ & $7 / 13(65.00 \%)$ \\
\hline & SPGRP biofilm & $7 / 15(68.18 \%)$ & $3 / 19(86.36 \%)$ & $4 / 16(80.00 \%)$ \\
\hline & PEM biofilm & $5 / 13(72.22 \%)$ & $3 / 20(86.96 \%)$ & $3 / 18(85.71 \%)$ \\
\hline
\end{tabular}

${ }^{1}$ Same bands are defined as the same location on the DGGE profile in Figure 3.

${ }^{2}$ Different bands are defined as the total number of different bands obtained when comparing each of two samples.

${ }^{3}$ The difference ratio is defined as the ratio of the number of different bands to all bands present.

of biofilms on the SPGRP, which plays an important role in the generation of electricity. Biofilms were observed to cover a high specific surface area on the SPGRPs forming both the cathode and the anode. Some aerobic bacteria might possibly be acting as cathode catalysts. The performance of a MFC has been found to increase as the biofilm develops on the cathode [26] and a high PD has been found when there is a biofilm covering the anode. This might be because the production of various biointermediates may favor electricity generation. Bacteria are able to use their respiratory chain as part of the oxidative metabolism that occurs at the anode. Nitrite might be converted to nitrate when the cathodic electrode acts as the electron donor due to denitrification in the MFC.

The $P D$ value is higher than that in previous studies using two-chambered MFCs that have had chemical mediators added. For example, an anaerobic-aerobic sequential reactor was reported to generate $387 \mathrm{~mW} / \mathrm{m}^{2} \mathrm{PD}$ and $5.2 \% C_{E}$ with $86.4 \%$ removal efficiency when high strength dye wastewater was used that comprised 1,000 $\mathrm{mg} \mathrm{L}^{-1}$ glucose and $200 \mathrm{mg} / \mathrm{L}$ Congo red (chemical mediator); this was at a longer HRT of $14.8 \mathrm{~h}$ [27]. A MFC shows $91 \%$ removal efficiency of highloading domestic wastewater with the volatile fatty acid/ hydrogen production which contained concentrated particular artificial food waste. The overall aim of converting chemical energy into electrical energy was achieved with a $C_{E}$ of $46 \%$ generating $65.33 \mathrm{~mA} / \mathrm{m}^{2}$ at a specific cell potential of $148 \mathrm{mV}$ [28]. However, other factors can affect the generation of electricity in the MFC A/O system. The characteristics of the wastewater can affect the electrical generation performance of MFCs. The slow biodegradations of the PPCPs present in the sewage used in this study might result in more efficient electricity production. Another possible reason is that the mass transfer of protons remains a major constraint affecting the $C_{E}$ of a MFC. The low $C_{E}$ values are due to the fact that hydrogen proton exchange through the PEM is retarded by bacterial fouling of the A/O system. It is possible that the high internal electric resistance of the novel design for a MFC system described here might decrease electricity generation performance. Nevertheless, the dual chamber MFC A/O system still is competitive if we are considering the biological treatment efficiency of PPCP sewage and the generation of electricity at the same time.

3.4. The Presence of Specific Bacterial Communities in the MFC $A / O$ System. Figure 5 displays the biodiversity of bacterial community in the MFC A/O systems by comparing their DGGE profiles. Table 4 compares the RI values for the DGGE

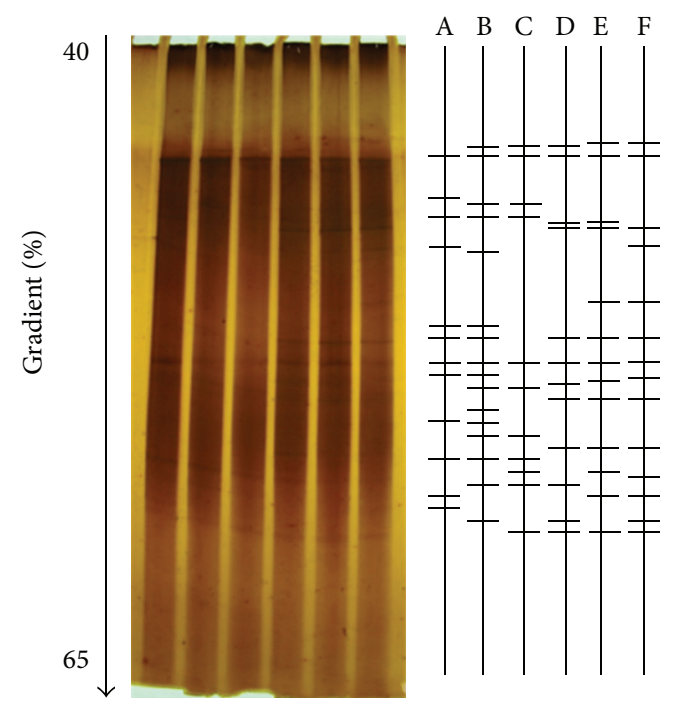

FIGURE 5: DGGE profiles analysis of the MFC A/O reactor in the MFC A/O system on the 109th day. Lines A, B, and C present the profiles of the MLSS, SPGRP biofilm, and PEM biofilm from the aerobic tank; lines D, E, and F present the profiles of the MLSS, SPGRP biofilm, and PEM biofilm from the anoxic reactor.

bands detected across the different bacterial populations. Distinct differences were found in the bacterial species present at the three sampling locations within the MFC A/O system. The highest difference in band number ratios was $86.96 \%$ and this occurred between the SPGRP biofilms in the anoxic reactor and the PEM biofilms in the aerobic reactor. Even the lowest difference in band number ratios was as high as $65.00 \%$, which was between the PEM biofilms in anoxic reactor and MLSS in aerobic reactor. These findings indicate the various different bacterial communities are likely to play distinctly different roles in the two chambers. For example, redox shuttling within the MFC anoxic chamber appears mainly to be present within the SPGRP and PEM biofilms and does not seem to occur within the MLSS biofilm.

Figure 6 provides detailed information on the various bacterial communities in the MFC A/O system at the classlevel species using the $16 \mathrm{~S}$ rDNA clone library. The dominant bacteria in the aerobic reactor were Proteobacteria, including $\beta$-Proteobacteria (53.50\%), $\delta$-Proteobacteria $(14.65 \%)$, $\gamma$-Proteobacteria (8.92\%), and $\alpha$-Proteobacteria (8.92\%). In addition, in terms of the three sampling locations within the reactor, the dominant species at the phylum-level are 


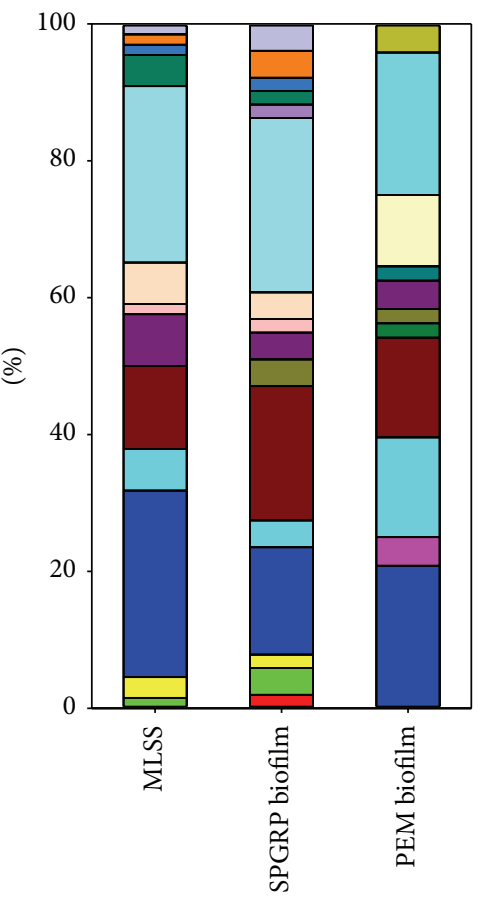

(a)

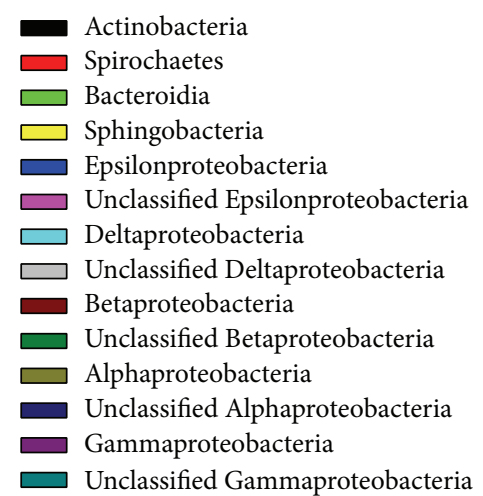

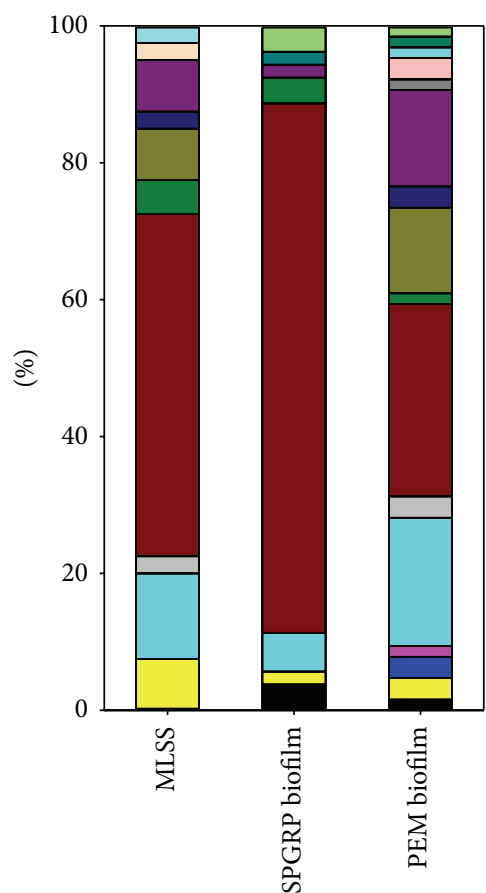

(b)

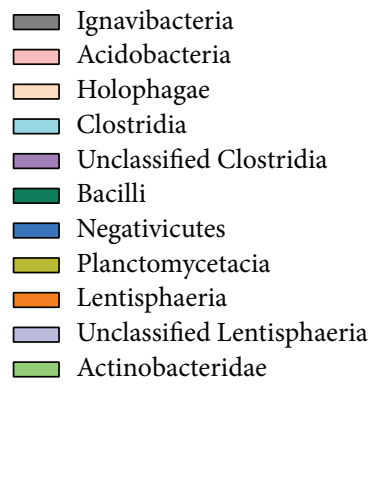

Figure 6: Bacterial community analysis of the MFC A/O reactor. The ratio of identified bacterial species to all bacteria cloned on the 114th day (class level): (a) anoxic reactor; (b) aerobic reactor.

different. The percentage of $\beta$-Proteobacteria was $81.13 \%$ within the GRP biofilms, compared to $55.0 \%$ within the MLSS and $29.69 \%$ within the PEM biofilms. The relative abundance of $\beta$-Proteobacteria is probably due to the fact that several groups of aerobic or facultative bacteria are well equipped to carry out aromatic degradation. In contrast, higher percentages of $\alpha$-Proteobacteria, $\gamma$-Proteobacteria, $\delta$ Proteobacteria, and Sphingobacteria were found to be present in the MLSS and PEM biofilms, but these groups were found to be much less abundant in the GRP biofilm. Furthermore, the anoxic reactor within the $\mathrm{A} / \mathrm{O}$ system was found to have a specific dominant bacterial community that included Clostridia-Firmicutes (24.85\%), $\varepsilon$-Proteobacteria (23.03\%), $\beta$-Proteobacteria (15.76\%), Bacteroidetes (10.16\%), and $\delta$ Proteobacteria $(7.88 \%)$. Many of these phyla can act as anoderespiring bacteria, which are defined as a bacterial population with a respiration process that can use an anode as their electron acceptor [13]. The percentage of $\varepsilon$-Proteobacteria in the MLSS was $27.27 \%$ and in the PEM biofilms was $25.0 \%$, which should be compared with that in the GRP biofilms, which was $15.68 \%$. Clostridia and $\beta$-Proteobacteria were dominant in this reactor with ranges from $20.83 \%$ to $27.45 \%$ and from $12.12 \%$ to $19.61 \%$ for the three different samples, respectively. Bacterial diversity has been found to vary at the anode of the MFCs when various different substrates are fed. For example, a two-chambered MFC using chocolate industry wastewater as the substrate had the following phyla at the anode: $\alpha$-Proteobacteria (9.1\%), $\beta$-Proteobacteria (50.6\%), $\gamma$ Proteobacteria (0.8\%), and Firmicutes (4.9\%) [29].

\section{Discussion}

4.1. Comparison of PPCP Removal in the Anoxic and Anaerobic Reactors. The contribution to PPCP treatment of the 
TABLE 5: Bacteria identified by nucleic acid sequencing of $16 \mathrm{~S}$ gene clones and by the searching of the GenBank database; these bacteria are associated with the generation of electricity by the MFC A/O system.

\begin{tabular}{lcl}
\hline Accession number (closest match) & Sequence similarity & Species \\
\hline KC502887 & $96 \%$ & Uncultured Geobacter sp. \\
FR774807 & $98 \%$ & Uncultured Clostridiales bacterium \\
FJ269104 & $96 \%$ & Iron-reducing bacterium \\
DQ234216 & $99 \%$ & Uncultured Sulfurospirillum bacterium \\
JF809001 & $100 \%$ & Uncultured Leptothrix sp. \\
JQ278984 & $99 \%$ & Uncultured Rhodospirillales bacterium \\
KC517355 & $87 \%$ & Pelosinus sp. \\
JQ086873 & $97 \%$ & Uncultured Treponema sp. \\
CU926806 & $97 \%$ & Uncultured Lentisphaerae sp. \\
KC871534 & $99 \%$ & Pseudomonas sp. \\
AF170354 & $99 \%$ & Dechloromonas sp. \\
HE662651 & $98 \%$ & Cupriavidus basilensis \\
\hline
\end{tabular}

aerobic reactor and of the anoxic reactor was found to be different in this MFC A/O system. The removal efficiency in the anoxic reactor averaged $62.51 \%$ for ACE, $51.88 \%$ for IBU, and $51.13 \%$ for SMX, but there was lower removal efficiency for ACE, IBU, and SMX in the aerobic reactor at $37.86 \%$, 47.14 , and $46.84 \%$, respectively. Their biointermediates in the anoxic reactor consist of at least three known compounds (data not shown). Aerobic biodegradation has generally been demonstrated to give a better removal efficiency of $\mathrm{COD}_{\mathrm{Cr}}$, which includes most of PPCPs. For example, $50 \mu \mathrm{g} / \mathrm{L}$ of ACE and IBU were biotransformed by greater than $80 \%$ after 10 days under aerobic batch biodegradation [30]. The removal efficiency of IBU reached $95 \pm 4 \%$ in an aerobic nitrification reactor but was only $37 \pm 26 \%$ in an anoxic denitrification reactor. Very low removal of SMX by biodegradation, 22 \pm $5 \%$ was found in an aerobic reactor in one study [31]. In the present MFC A/O system, the anoxic reactor can remove more of the target PPCPs because of the obvious growth of facultative bacteria within the MLSS and SPGRP biofilms. These bacterial populations were able to bring about removal rates for the PPCPs as follows: ACE (62.51\%) > IBU (51.88\%), both under anoxic condition. In one previous study, there was IBU biodegradation at $28 \%$, with the concentration being $78 \mathrm{mg} / \mathrm{L}$, which contrasted with the result for ACE at $11 \%$, with the concentration being $66.12 \mathrm{mg} / \mathrm{L}$, during anaerobic degradation at $37^{\circ} \mathrm{C}$ for 56 days [32].

\subsection{Bacterial Species Involved in the Generation of Electricity} by the MFC A/O System. Using a complex substrate like domestic wastewater that contains high strength PPCPs can help establish a diverse and electrochemically active microbial community using the MFC system. Some species in bacteria population that are able to produce electricity in a MFC were found to be abundant. Extracellular electron transfer was defined as electrons retrieved from the microbial oxidation of the organic substrates, namely, PPCP-containing sewage, in this study; these are then transferred to the anode. Table 5 shows the specific bacterial species identified as being most closely related to the various MFC bacteria that have been identified in MFC systems. Anodophilic consortia, such as Geobacteraceae (identified as Geobacter spp. in this study), Clostridiaceae (identified as Clostridium spp. in this study, $10.24 \%$ clones), and various Proteobacteria species, have been shown to be able to generate a current in an anode chamber and are known to be able to transfer electrons to an electrode. For example, iron-reducing bacteria such as Shewanella and Geobacter spp. have been described as electrochemically active bacteria in MFC systems [33-35]. A Leptothrix sp. has been reported to be a type of Mn-oxidizing bacteria that bioaccumulates $\mathrm{Mn}$ oxides that can be used as cathodic reactants. The potential of a MFC that includes the reduction of Mn oxides deposited by Leptothrix spp. can be increased to about $300 \mathrm{mV}$ and is able to deliver a current density up to two orders of magnitude higher than that reached using the reduction of $\mathrm{O}_{2}$ [36]. Rhodospirillales bacterium has been shown to be dominant in a cathodic MLSS rather than a biofilm; one possible reason for this is the fact that this is a light utilizing bacterial group capable of obtaining better illumination in suspension than as a biofilm [33]. Pelosinus spp. are capable of fermenting lactate and coupling the oxidation of this compound to $\mathrm{Fe}^{3+}$; and such metal reduction in a microbial fuel cell can produce a maximum $\mathrm{PD}$ of $4.1 \mathrm{~mW} / \mathrm{m}^{2}$ [34]. A Treponema sp. has been found to be present in a twochambered PEM MFC that utilized active sludge enriched with chocolate industry wastewater [29]. A Lentisphaerae sp. has been found previously to be associated with the anode of a MFC system [37]. A Pseudomonas sp., a facultative anaerobic bacterium, is able to produce pyocyanin as a mediator and then uses these quorum signaling compounds to produce power [35]. A Dechloromonas sp. was identified as the most dominant species of anode bacteria in a butyrate-fed twochamber MFC system [38]. Cupriavidus basilensis has been shown to be involved in current production in a microbial fuel cell that used either acetate or phenol as a carbon source; in this case after $72 \mathrm{~h}$ in the MFC, $86 \%$ of the initial phenol concentration had been removed [39].

4.3. Bacterial Species Involved in the Biodegradation of PPCPS and Aromatic Compounds by the MFC A/O System. Table 6 outlines the specific bacterial species that are equipped 
TABLE 6: Bacteria identified by nucleic acid sequencing of $16 \mathrm{~S}$ gene clones and by the searching of the GenBank database; these are associated with the biodegradation of PPCP and aromatic compounds in the MFC A/O system.

\begin{tabular}{lcl}
\hline Accession no (Closest match) & Sequences similarity & Species \\
\hline KC871534 & $99 \%$ & Pseudomonas sp. \\
AJ620198 & $99 \%$ & Sphingomonas sp. \\
AF170354 & $99 \%$ & Dechloromonas sp. \\
KC871534 & $96 \%$ & Uncultured Geobacter sp. \\
AB636293 & $97 \%$ & Uncultured Hydrogenophaga sp. \\
HE662651 & $98 \%$ & Cupriavidus sp. \\
HQ184339 & $98 \%$ & Uncultured Zoogloea sp. \\
JQ795417 & $96 \%$ & Uncultured Acidobacteria bacterium \\
KC310815 & $99 \%$ & Staphylococcus sp. \\
JQ723636 & $96 \%$ & Uncultured Sphingobacteriales bacterium \\
JN540151 & $95 \%$ & Uncultured Prolixibacter sp. \\
JF808996 & $99 \%$ & Uncultured Burkholderiaies bacterium \\
\hline
\end{tabular}

with the ability to biodegrade aromatic compounds such as PPCPs, and these include bacteria associated with anaerobic biotransformation and aerobic ring cleavage, both of which were identified in the present study. Three species are known to have a direct relationship with PPCP biodegradation. Dechloromonas spp., which are $\beta$-Proteobacteria, have been detected in an $\mathrm{A} / \mathrm{O}-\mathrm{MBR}$ process that demonstrated good removal efficiency (88.5-99.5\%) of antibiotics, including $500 \mu \mathrm{g} / \mathrm{L}$ SMX, at various different HRTs [40]. Pseudomonas spp. have been reported to biodegrade many pharmaceutical pollutants. For example, a high concentration of 2,000 mg/L ACE was able to be completely biodegraded as sole carbon source by a Pseudomonas aeruginosa isolated from the SBR treatment plant that processed ACE-contaminated wastewater [41]. Pseudomonas aeruginosa is also able to biodegrade $1.3 \%$ of $6 \mathrm{mg} / \mathrm{L} \mathrm{SMX}$ when this antibiotic is used as sole carbon source or $5.6 \%$ of $6 \mathrm{mg} / \mathrm{L}$ SMX when $0.5 \mathrm{~g} / \mathrm{L}$ glucose is present as an additive [42]. In addition, a Sphingomonas sp. strain Ibu-2, which was found in a wastewater treatment plant, was shown to be able to biodegrade $500 \mathrm{mg} / \mathrm{L} \mathrm{IBU}$ as sole carbon and energy source over $80 \mathrm{hrs}$ [43]. Bacterial communities seem to have adapted to IBU biodegradation best under anoxic conditions. In such circumstances the biological degradation rate constant for IBU with time was found to increase from $16 \%$ at the beginning to $75 \%$ after 350 days.

The chemical structure of the biological metabolic products derived from PPCPs consists largely of benzene-ring compounds. Anaerobic benzene biodegradation by Geobacter sp. has been shown to occur in a petroleum-contaminated aquifer [44]. A Hydrogenophaga sp., which is a member of a heterogeneous aerobic benzene-degrading bacterial group, was found during the biological treatment in BTEX groundwater [45]. An overall 95\% biodegradation of the ligninrelated aromatic compound ferulic acid has been reported to occur with a Cupriavidus sp. when ferulic acid is used as a sole carbon and energy source [46]. A Zoogloea sp. has been shown to be able to biodegrade $98.6 \%$ of lubricating oil over 12 days with a HRT of $6 \mathrm{~h}$. and an inflow rate of $33 \mathrm{~L} / \mathrm{h}$ [47]. An Acidobacteria bacterium was found to be the dominant bacterial group during $\mathrm{PAH}$ bioremediation
(3-5 aromatic rings) in soil and was also shown to be able to degrade benzene contaminated groundwater [48, 49]. A Staphylococcus sp., when immobilized on vermiculite, was used to remove hydrocarbons; this system used a fluidized bed bioreactor and synthetic water polluted with benzene, toluene, or naphthalene as sole sources of carbon and energy [50]. A Sphingobacteriales bacterium has been identified as part of an ethylbenzene-degrading sulfate-reducing consortium [51]. A Prolixibacter sp. has been identified by microbial enrichment to be able to biodegrade chlorinated pesticides that are present in contaminated sites of different geographical habitats of India [52]. A Burkholderiales bacterium has been identified as being able to degrade methyl tert-butyl ether (MTBE), a benzene, toluene, ethylbenzene, and xylene (BTEX) mixture, and tert-butyl alcohol (TBA) [53].

\section{Conclusions}

The pilot-scale MFC A/O sewage treatment was easily equipped with SPGRPs in order to treat municipal wastewater and to generate electricity in parallel with the biodegradation. The biological treatment of the PPCP-contained sewage demonstrated good performance over the time course of the experiment. A high removal efficiency of the target PPCPs was obtained after biofilms had formed on large specific surface areas available within the MFC A/O system. The ability to generate electricity using the SPGRP MFC is better than previous dual-chamber graphite MFC systems. A total of twenty bacterial species were identified as forming part of the MLSS and SPGRP biofilms and these identifications were used to clarify the possible functions of these microorganisms. These functions included both electrical generation and PPCP biodegradation. Practically, a scale-up of this SPGRP MFC A/O system for the treatment of real PPCP-contained sewage is needed and this should be applied to a commercial operation in the future. This will allow the design, operation, and maintenance of the system to be optimized. Importantly, such a system should be more efficient in terms of power use than conventional systems, without a significant increase in construction costs. 


\section{Conflict of Interests}

The authors declare that there is no conflict of interests regarding the publication of this paper.

\section{Acknowledgments}

The authors thank Professor Ilona Sárvári Horváth for the discussion and comments. Ms. Ruo-Jhen Peng made her great effort to help with the experimental tasks. This work was supported by the National Science Council (NSC) of Taiwan through the project NSC100-2632-B-031-001-MY3.

\section{References}

[1] D. W. Kolpin, E. T. Furlong, M. T. Meyer et al., "Pharmaceuticals, hormones, and other organic wastewater contaminants in U.S. streams, 1999-2000: a national reconnaissance," Environmental Science and Technology, vol. 36, no. 6, pp. 1202-1211, 2002.

[2] A. Y. Lin, C. Lin, Y. Tsai et al., "Fate of selected pharmaceuticals and personal care products after secondary wastewater treatment processes in Taiwan," Water Science and Technology, vol. 62 , no. 10 , pp. 2450-2458, 2010.

[3] Y. J. Chan, M. F. Chong, C. L. Law, and D. G. Hassell, "A review on anaerobic-aerobic treatment of industrial and municipal wastewater," Chemical Engineering Journal, vol. 155, no. 1-2, pp. $1-18,2009$.

[4] J. Reungoat, B. I. Escher, M. Macova, and J. Keller, "Biofiltration of wastewater treatment plant effluent: effective removal of pharmaceuticals and personal care products and reduction of toxicity," Water Research, vol. 45, no. 9, pp. 2751-2762, 2011.

[5] L. Zhou, G. Ying, S. Liu et al., "Occurrence and fate of eleven classes of antibiotics in two typical wastewater treatment plants in South China," Science of the Total Environment, vol. 452-453, pp. 365-376, 2013.

[6] D. Pant, D. Arslan, G. V. Bogaert et al., "Integrated conversion of food waste diluted with sewage into volatile fatty acids through fermentation and electricity through a fuel cell," Environmental Technology, vol. 34, no. 13-14, pp. 1935-1945, 2013.

[7] A. ElMekawy, S. Srikanth, K. Vanbroekhoven, H. D. Wever, and D. Pant, "Bioelectro-catalytic valorization of dark fermentation effluents by acetate oxidizing bacteria in bioelectrochemical system (BES)," Journal of Power Sources, vol. 262, pp. 183-191, 2014.

[8] J. Zhang, Y. Zhang, X. Quan et al., "An anaerobic reactor packed with a pair of Fe-graphite plate electrodes for bioaugementation of azo dye wastewater," Biochemical Engineering Journal, vol. 63, pp. 31-37, 2012.

[9] Y. Liu, H. Liu, C. Wang, S. X. Hou, and N. Yang, "Sustainable energy recovery in wastewater treatment by microbial fuel cells: stable power generation with nitrogen-doped graphene cathode," Environmental Science Technology, vol. 47, no. 23, pp. 13889-13895, 2013.

[10] Y. Alvarez-Gallego, X. Dominguez-Benetton, D. Pant et al., "Development of gas diffusion electrodes for cogeneration of chemicals and electricity," Electrochimica Acta, vol. 82, pp. 415426, 2012.
[11] T. Sangeetha and M. Muthukumar, "Influence of electrode material and electrode distance on bioelectricity production from sago-processing wastewater using microbial fuel cell," Environmental Progress \& Sustainable Energy, vol. 32, no. 2, pp. 390-395, 2013.

[12] K. Rabaey and W. Verstraete, "Microbial fuel cells: novel biotechnology for energy generation," Trends in Biotechnology, vol. 23, no. 6, pp. 291-298, 2005.

[13] L. Alzate-Gaviria, "Microbial fuel cells for wastewater treatment," in Waste Water-Treatment and Reutilization, F. Sebastián and G. Einschlag, Eds., InTech, 2011.

[14] APHA, AWWA, and WEF, Standard Methods for the Examination of Water and Wastewater, American Public Health Association, American Water Works Association, Water Environment Federation, Washington, DC, USA, 22th edition, 2012, edited by E. W. Rice, R.B. Baird, L. S. Clesceri , A. D. Eaton.

[15] H.-L. Chou, Y.-T. Chang, Y.-F. Liao, and C.-H. Lin, "Biodegradation of decabromodiphenyl ether (BDE-209) by bacterial mixed cultures in a soil/water system," International Biodeterioration Biodegradation, vol. 85, pp. 671-682, 2013.

[16] A. L. Reysenbach and N. R. Pace, "Archaea: laboratory manualthermophiles," F. T. Robb and A. R. Place, Eds., Cold Spring Harbour Laboratory Press, New York, NY, USA, 1995.

[17] S. K. Behera, H. W. Kim, J. Oh, and H. Park, "Occurrence and removal of antibiotics, hormones and several other pharmaceuticals in wastewater treatment plants of the largest industrial city of Korea," Science of the Total Environment, vol. 409, no. 20, pp. 4351-4360, 2011.

[18] T. Alvarinoa, K. Evina, S. Malamis, S. Suarez, F. Omil, and F. Fatone, "Inhibition of biomass activity in the via nitrite nitrogen removal processes by veterinary pharmaceuticals," Bioresource Technology, vol. 152, pp. 477-483, 2014.

[19] J. Radjenović, M. Petrović, and D. Barceló, "Fate and distribution of pharmaceuticals in wastewater and sewage sludge of the conventional activated sludge (CAS) and advanced membrane bioreactor (MBR) treatment," Water Research, vol. 43, no. 3, pp. 831-841, 2009.

[20] F. Ingerslev and B. Halling-Sorensen, "Biodegradability properties of sulfonamides in activated sludge," Environmental Toxicology and Chemistry, vol. 19, no. 10, pp. 2467-2473, 2000.

[21] F. I. Hai, X. Li, W. E. Price, and L. D. Nghiem, "Removal of carbamazepine and sulfamethoxazole by MBR under anoxic and aerobic conditions," Bioresource Technology, vol. 102, no. 22, pp. 10386-10390, 2011.

[22] S. Thiele-Bruhn, "Pharmaceutical antibiotic compounds in soils-a review," Journal of Plant Nutrition and Soil Science, vol. 166, no. 2, pp. 145-167, 2003.

[23] L. H. Santos, M. Gros, S. Rodriguez-Mozaz et al., "Contribution of hospital effluents to the load of pharmaceuticals in urban wastewaters: identification of ecologically relevant pharmaceuticals," Science of the Total Environment, vol. 461-462, pp. 302 316, 2013.

[24] S. C. Antunes, R. Freitas, E. Figueira, F. Gonçalves, and B. Nunes, "Biochemical effects of acetaminophen in aquatic species: edible clams Venerupis decussata and Venerupis philippinarum," Environmental Science and Pollution Research, vol. 20, no. 9, pp. 6658-6666, 2013.

[25] H. J. De Lange, W. Noordoven, A. J. Murk, M. Lürling, and E. T. H. M. Peeters, "Behavioural responses of Gammarus pulex (Crustacea, Amphipoda) to low concentrations of pharmaceuticals," Aquatic Toxicology, vol. 78, no. 3, pp. 209-216, 2006. 
[26] Z. He and L. T. Angenent, "Application of bacterial biocathodes in microbial fuel cells," Electroanalysis, vol. 18, no. 19-20, pp. 2009-2015, 2006.

[27] Z. Li, X. Zhang, J. Lin, S. Han, and L. Lei, "Azo dye treatment with simultaneous electricity production in an anaerobicaerobic sequential reactor and microbial fuel cell coupled system," Bioresource Technology, vol. 101, no. 12, pp. 4440-4445, 2010.

[28] E. Elakkiya and M. Matheswaran, "Comparison of anodic metabolisms in bioelectricity production during treatment of dairy wastewater in Microbial Fuel Cell," Bioresource Technology, vol. 136, pp. 407-412, 2013.

[29] S. A. Patil, V. P. Surakasi, S. Koul et al., "Electricity generation using chocolate industry wastewater and its treatment in activated sludge based microbial fuel cell and analysis of developed microbial community in the anode chamber," Bioresource Technology, vol. 100, no. 21, pp. 5132-5139, 2009.

[30] J. T. Yu, E. J. Bouwer, and M. Coelhan, "Occurrence and biodegradability studies of selected pharmaceuticals and personal care products in sewage effluent," Agricultural Water Management, vol. 86, no. 1-2, pp. 72-80, 2006.

[31] S. Suarez, J. M. Lema, and F. Omil, "Removal of pharmaceuticals and personal care products (PPCPs) under nitrifying and denitrifying conditions," Water Research, vol. 44, no. 10, pp. 3214-3224, 2010.

[32] S. E. Musson, P. Campo, T. Tolaymat, M. Suidan, and T. G. Townsend, "Assessment of the anaerobic degradation of six active pharmaceutical ingredients," Science of the Total Environment, vol. 408, no. 9, pp. 2068-2074, 2010.

[33] K. B. Gregory, D. R. Bond, and D. R. Lovley, "Graphite electrodes as electron donors for anaerobic respiration," Environmental Microbiology, vol. 6, no. 6, pp. 596-604, 2004.

[34] S. Choi and J. Chae, "Optimal biofilm formation and power generation in a micro-sized microbial fuel cell (MFC)," Sensors and Actuators, A: Physical, vol. 195, pp. 206-212, 2013.

[35] B. E. Logan, "Exoelectrogenic bacteria that power microbial fuel cells," Nature Reviews Microbiology, vol. 7, no. 5, pp. 375-381, 2009.

[36] A. Rhoads, H. Beyenal, and Z. Lewandowski, "Microbial fuel cell using anaerobic respiration as an anodic reaction and biomineralized manganese as a cathodic reactant," Environmental Science and Technology, vol. 39, no. 12, pp. 4666-4671, 2005.

[37] G. Zhang, K. Wang, Q. Zhao, Y. Jiao, and D. Lee, "Effect of cathode types on long-term performance and anode bacterial communities in microbial fuel cells," Bioresource Technology, vol. 118, pp. 249-256, 2012.

[38] K.-J. Chae, M.-J. Choi, J.-W. Lee, K.-Y. Kim, and I. S. Kim, "Effect of different substrates on the performance, bacterial diversity, and bacterial viability in microbial fuel cells," Bioresource Technology, vol. 100, no. 14, pp. 3518-3525, 2009.

[39] H. Friman, A. Schechter, Y. Ioffe, Y. Nitzan, and R. Cahan, "Current production in a microbial fuel cell using a pure culture of Cupriavidus basilensis growing in acetate or phenol as a carbon source," Microbial Biotechnology, vol. 6, no. 4, pp. 425434, 2013.

[40] S. Xia, R. Jia, F. Feng et al., "Effect of solids retention time on antibiotics removal performance and microbial communities in an A/O-MBR process," Bioresource Technology, vol. 106, pp. 3643, 2012.
[41] B. de Gusseme, L. Vanhaecke, W. Verstraete, and N. Boon, "Degradation of acetaminophen by Delftia tsuruhatensis and Pseudomonas aeruginosa in a membrane bioreactor," Water Research, vol. 45, no. 4, pp. 1829-1837, 2011.

[42] S. Larcher and V. Yargeau, "Biodegradation of sulfamethoxazole by individual and mixed bacteria," Applied Microbiology and Biotechnology, vol. 91, no. 1, pp. 211-218, 2011.

[43] R. W. Murdoch and A. G. Hay, "Formation of catechols via removal of acid side chains from ibuprofen and related aromatic acids," Applied and Environmental Microbiology, vol. 71, no. 10, pp. 6121-6125, 2005.

[44] J. N. Rooney-Varga, R. T. Anderson, J. L. Fraga, D. Ringelberg, and D. R. Lovley, "Microbial communities associated with anaerobic benzene degradation in a petroleum-contaminated aquifer," Applied and Environmental Microbiology, vol. 65, no. 7, pp. 3056-3063, 1999.

[45] A. Fahy, T. J. McGenity, K. N. Timmis, and A. S. Ball, "Heterogeneous aerobic benzene-degrading communities in oxygendepleted groundwaters," FEMS Microbiology Ecology, vol. 58, no. 2, pp. 260-270, 2006.

[46] L. Chai, H. Zhang, W. Yang et al., "Biodegradation of ferulic acid by a newly isolated strain of Cupriavidus sp. B-8," Journal of Central South University, vol. 20, no. 7, pp. 1964-1970, 2013.

[47] J. Liang, X. J. Wang, Z. L. Gu, D. Z. Zhou, and S. Q. Xie, "Biodegradation of lubricating oil in wastewater with Zoogloea sp.," Pedosphere, vol. 16, no. 4, pp. 540-544, 2006.

[48] J. Mao, Y. Luo, Y. Teng, and Z. Li, "Bioremediation of polycyclic aromatic hydrocarbon-contaminated soil by a bacterial consortium and associated microbial community changes," International Biodeterioration and Biodegradation, vol. 70, pp. 141-147, 2012.

[49] S. Xie, W. Sun, C. Luo, and A. M. Cupples, "Novel aerobic benzene degrading microorganisms identified in three soils by stable isotope probing," Biodegradation, vol. 22, no. 1, pp. 71-81, 2011.

[50] J. Taoufik, Y. Zeroual, A. Moutaouakkil et al., "Aromatic hydrocarbons removal by immobilized bacteria (Pseudomonas sp., Staphylococcus sp.) in fluidized bed bioreactor," Annals of Microbiology, vol. 54, no. 2, pp. 189-200, 2004.

[51] T. Nakagawa, S. Sato, Y. Yamamoto, and M. Fukui, "Successive changes in community structure of an ethylbenzene-degrading sulfate-reducing consortium," Water Research, vol. 36, no. 11, pp. 2813-2823, 2002.

[52] N. Manickam, A. Pathak, H. S. Saini, S. Mayilraj, and R. Shanker, "Metabolic profiles and phylogenetic diversity of microbial communities from chlorinated pesticides contaminated sites of different geographical habitats of India," Journal of Applied Microbiology, vol. 109, no. 4, pp. 1458-1468, 2010.

[53] A. Pruden and M. Suidan, "Effect of benzene, toluene, ethylbenzene, and p-xylene (BTEX) mixture on biodegradation of methyl tert-butyl ether (MTBE) and tert-butyl alcohol (TBA) by pure culture UC1," Biodegradation, vol. 15, no. 4, pp. 213-227, 2004. 

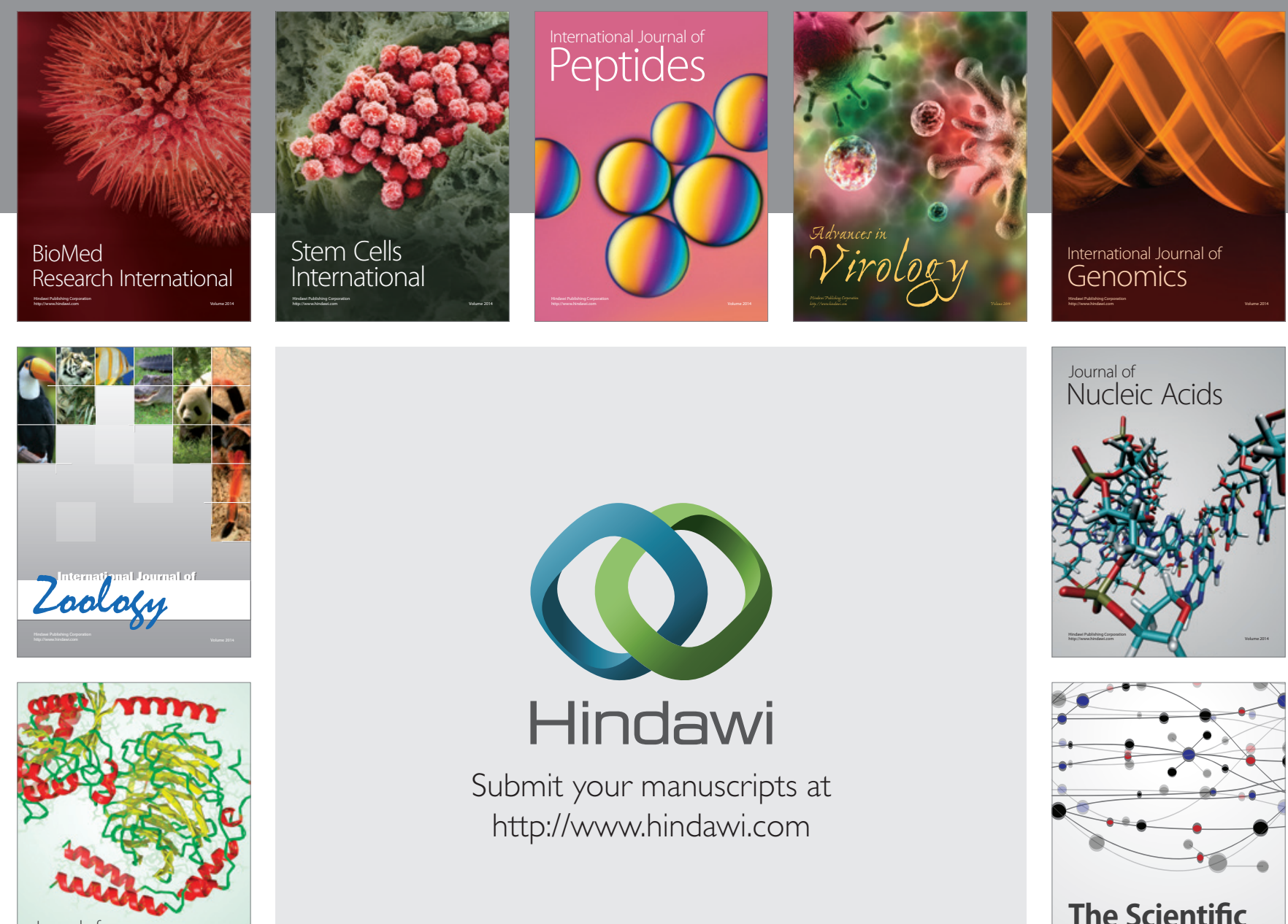

Submit your manuscripts at

http://www.hindawi.com

Journal of
Signal Transduction
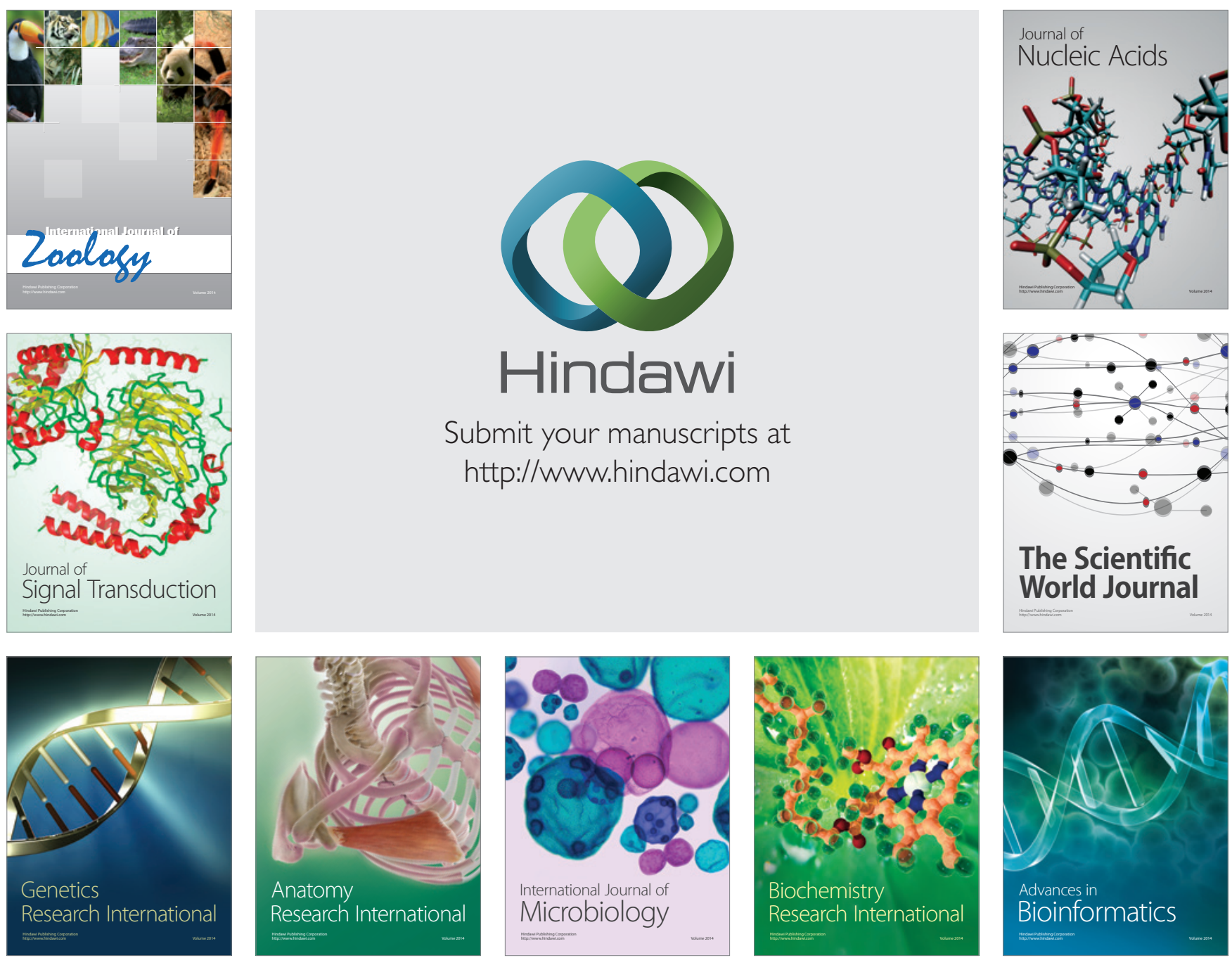

The Scientific World Journal
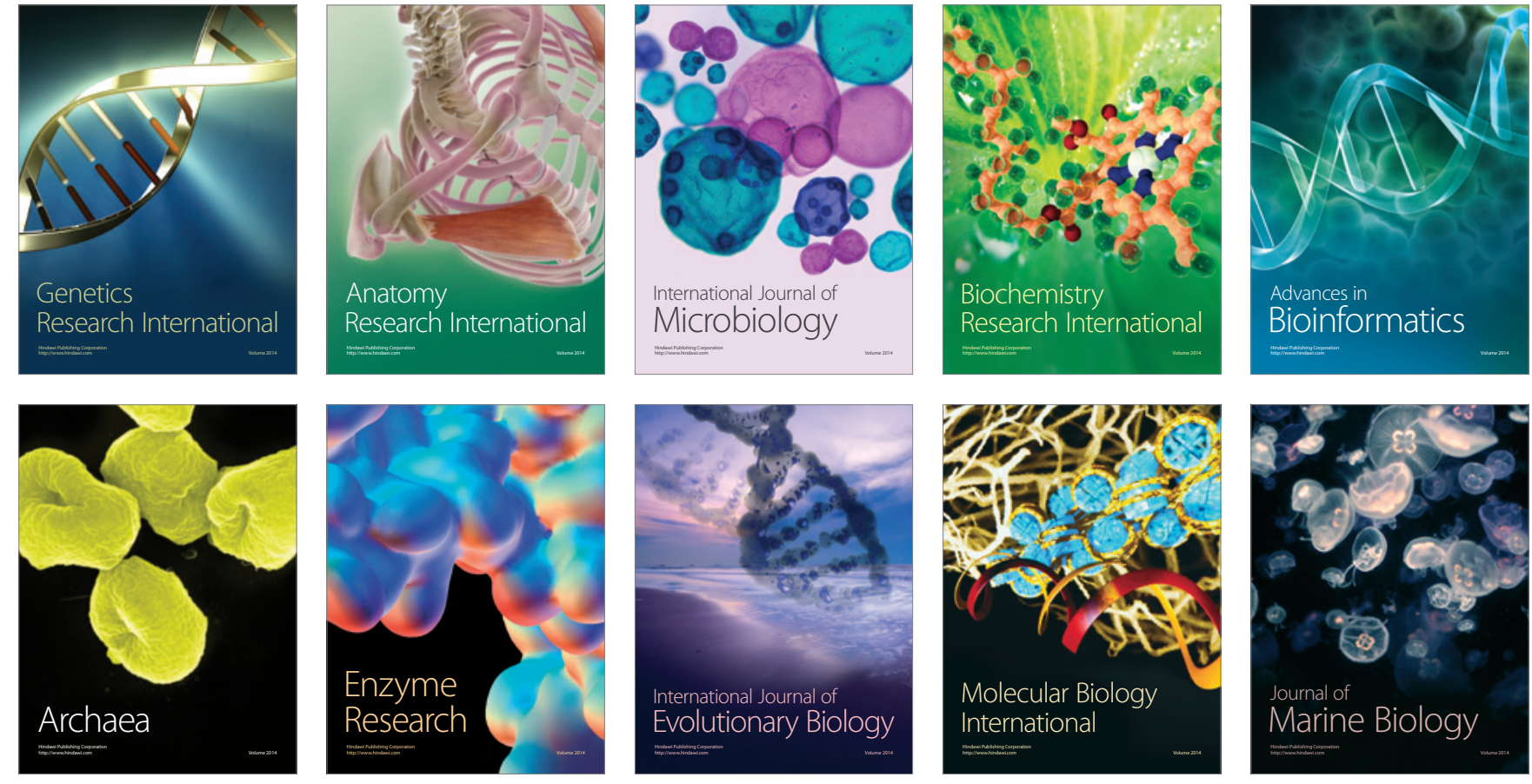